\title{
Use of glycosaminoglycans from Oreochromis niloticus skin as an antioxidant supplement for milt cryopreservation of Brazilian bocachico
}

\author{
Uso de glicosaminoglicanos da pele Oreochromis \\ niloticus como suplemento antioxidante na \\ criopreservação de sêmen de curimatã comum \\ (Prochilodus brevis)
}

\begin{abstract}
Renata Vieira do Nascimento ${ }^{1 *}$; Vanessa Alves Pereira ${ }^{1}$; Priscila Silva de AlmeidaMonteiro"; Yara Silvino Sales2; Ianna Wivianne Fernandes de Araújo3; José Ariévilo Gurgel Rodrigues ${ }^{4}$; Thaís de Oliveira Costa5; Andressa Gomes de Oliveira6; Assis Rubens Montenegro7; Carminda Sandra Brito Salmito-Vanderley ${ }^{8}$
\end{abstract}

\section{Highlights}

Glycosaminoglycans (GAGs) extracted from Nile tilapia skin have antioxidant action. Lower GAGs concentrations are indicated for sperm cryopreservation of P. brevis. GAGs did not decrease morphology, membrane integrity, and sperm DNA of P. brevis.

\begin{abstract}
The study aimed to evaluate the in vitro antioxidant action of glycosaminoglycans (GAGs) from the skin of Oreochromis niloticus, and to determine their ideal concentration to supplement the sperm freezing medium of Prochilodus brevis. In experiment 1, the in vitro antioxidant properties of GAGs were verified through the analysis of DPPH, chelating ferrous ability, and total antioxidant capacity. In experiment 2, milt pools were formed, which were frozen in solution supplemented or not with different GAGs concentrations: 0 (control), $0.5,1.0,1.5,2.0,2.5,3.0,3.5,4.0,4.5$, or $5.0 \mathrm{mg} \mathrm{mL}^{-1}$ (total of 10 treatments). The samples were

1 Students of the Doctoral Course of the Postgraduate Program in Veterinary Sciences, Universidade Estadual do Ceará, UECE, Fortaleza, CE, Brazil. E-mail: renatavieiraa@hotmail.com; vanessabio35@gmail.com; priscilla_vs@hotmail.com

2 Biological Sciences Student, Fish Reproduction Biotechnology Laboratory, UECE, Fortaleza, CE, Brazil. E-mail: yara. sales@aluno.uece.br

3 Profa Dra in Department of Fishing Engineering, UFC, Fortaleza, Fortaleza, CE, Brazil. E-mail: iwfaraujo@gmail.com

${ }^{4}$ Researcher in Biotechnology of Aquatic Organisms, UFC, Fortaleza, CE, Brazil. E-mail: arieviloengpesca@yahoo.com.br

${ }^{5}$ Biological Sciences Student, Federal UFC, Fortaleza, CE, Brazil. E-mail: thaisocosta@hotmail.com

6 Fishery Engineering Student, UFC, Fortaleza, CE, Brazil. E-mail: and_ressa5@hotmail.com

7 Dr. in Zootechnics, Integrated Doctoral Program in Animal Science, UFC, Fortaleza, CE, Brazil. E-mail: assismontenegro@ yahoo.com.br

8 Profa Dra in Postgraduate Program in Veterinary Sciences, UFC, Fortaleza, CE, Brazil. E-mail: sandra.salmito@uece.br

* Author for correspondence
\end{abstract}

Received: Oct. 05, 2020 - Approved: May 18, 2021 
evaluated for membrane integrity, DNA integrity, sperm morphology, and sperm kinetics. The results of experiment 1 showed that the GAGs exhibited, with the increase of the concentration, significant antioxidant action, for all the evaluated tests, mainly in the chelating ferrous ability. In experiment 2, it was observed that the increase of GAGs concentration decreased kinetic parameters $(P<0.05)$, however, the control and $0.5 \mathrm{mg} \mathrm{mL}^{-1} \mathrm{GAGs}$ concentration showed similar results. For the other parameters (membrane integrity, DNA integrity, and sperm morphology), there was no decrease in results with the increase of GAGs concentration. In conclusion, GAGs extracted from $O$. niloticus skin have antioxidant action, and the concentration of $0.5 \mathrm{mg} \mathrm{mL}^{-1}$ was the most adequate to supplement the $P$. brevis sperm-freezing medium. Key words: Cryopreservation. Oxidative stress. Rheophilic fish. Spermatozoa kinetics. Sulfated glycans.

\section{Resumo}

O estudo teve como objetivo avaliar in vitro a ação antioxidante de glicosaminoglicanos (GAGs) da pele de Oreochromis niloticus e determinar sua concentração ideal para suplementar o meio de congelação espermático de Prochilodus brevis. No experimento 1, foram verificadas as propriedades antioxidantes in vitro dos GAGs por meio das análises de DPPH, capacidade quelante do ferro e capacidade antioxidante total. No experimento 2, foram formados pool de sêmen, que foram congelados em solução suplementada, ou não, com diferentes concentrações de GAGs: 0 (controle); 0,5; 1,0; 1,5; 2,0; 2,5; 3,0; 3,5;4,0;4,5 ou $5,0 \mathrm{mg} \mathrm{mL}^{-1}$ (total de 10 tratamentos). As amostras foram avaliadas quanto à integridade da membrana, integridade do DNA, morfologia e cinética espermática. Os resultados do experimento 1, mostraram que os GAGs exibiram, com o aumento da concentração, ação antioxidante significativa, para todos os testes avaliados, principalmente na capacidade quelante do ferro. No experimento 2, observou-se que o aumento da concentração de GAGs diminuiu os parâmetros cinéticos $(P<0,05)$, porém o controle e a concentração de $0,5 \mathrm{mg} \mathrm{mL}^{-1}$ de GAGs apresentaram resultados semelhantes. Para os demais parâmetros (morfologia, integridade de membrana e de DNA), não houve diminuição dos resultados com o aumento da concentração de GAGs. Em conclusão, os GAGs, extraídos da pele de $O$. niloticus, possuem ação antioxidante, sendo a concentração de $0,5 \mathrm{mg} \mathrm{mL}^{-1}$ a mais adequada para suplementar o meio de congelação espermático de P. brevis.

Palavras-chave: Cinética espermática. Criopreservação. Estresse oxidativo. Glicanos sulfatados. Peixe reofílico.

\section{Introduction}

\section{Prochilodus brevis (Steindachner,} 1875 ) is a rheophilic fish (Characiform, Prochilodontidae) from the Brazilian semiarid, known as Brazilian bocachico. Unfortunately, the construction of dams, drought, and overfishing during the reproductive period endanger the species survival (Gurgel, Verani, \& Chellappa, 2012). This is a concern because
$P$. brevis play an important ecological role in its environment, and also has social importance and economic value (Costa et al., 2015; Bomfim, Peretti, Camillo, Costa, \& Nascimento, 2015). Within this perspective, there is an interest in developing artificial reproduction techniques, such as seminal cryopreservation, to optimize the development of fish farming and the conservation of $P$. brevis in the natural environment. 
Studies related to the seminal cryopreservation of $P$. brevis have already been carried out, in which were tested different dilution rates (Lopes et al., 2014), forms of milt storage (Nascimento et al., 2017), forms of dilution (Lopes et al., 2014; Nunes et al., 2016) and freezing methods (Pinheiro et al., 2016). There is a good interaction of $P$. brevis sperm with the freezing medium composed of $5 \%$ glucose and $10 \%$ dimethyl sulfoxide (DMSO), both for sperm kinetics parameters (Nunes et al., 2016) and the fertilization capacity (Nunes et al., 2019). Besides, the use of this freezing medium with an addition of antioxidant agents, such as vitamin $\mathrm{C}$, shows good results for thawed sperm (Almeida-Monteiro et al., 2017). This confirms the importance of supplementing the freezing medium with compounds that improve its protective action, such as antioxidant agents.

Due to the scarcity of cytoplasm, there is a low amount of endogenous antioxidants in the spermatozoa, which makes these cells dependent on seminal plasma antioxidants (Shaliutina-Kolešová, Gazo, Cosson, \& Linhart, 2013). However, during sperm cryopreservation, it is necessary to dilute the milt in the freezing medium, which reduces the concentration of exogenous antioxidant agents. In addition, there is an increase in the production of reactive oxygen species (ROS) throughout the cryopreservation process (Cabrita et al., 2011; Figueroa et al., 2018). Thus, supplementing the freezing medium with antioxidant agents is a good strategy to improve sperm motility and post-thaw viability.

Sulfated polysaccharides are highly complex and heterogeneous polymers found in different organisms, which generally have antioxidant actions on ROS (Costa et al., 2010; Alencar et al., 2019). Due to the presence of sulfate radicals, they donate electrons and exercise reducing power (Jridi et al., 2019). In animals (vertebrates and invertebrates), such compounds are found in the form of glycosaminoglycans (GAGs) (Jridi et al., 2019) and play important biological roles in living organisms (Valcarcel, Novoa-Carballal, PérezMartín, Reis, \& Vázquez, 2017).

There are GAGs in teleost tissues, making part of their extracellular matrix, such as happens in the Nile tilapia (O. niloticus) (Salles et al., 2017). This species is one of the most cultivated fish in the world (Food and Agriculture Organization of the United Nations [FAO], 2018), which generates a high production of waste, including from its skin, which presents GAGs in the form of dermatan sulfate (Salles et al., 2017). Skin from $O$. niloticus, in gelatin form (70\% collagen), has high concentrations of substances that eliminate ROS (Zhang, Duan, \& Zhuang, 2012), and we believe that GAGs are also responsible for this property. Studies report that dermatan sulfate can act as an antithrombotic, anticoagulant, and anti-inflammatory agent (Valcarcel et al., 2017); however, there is no investigation on its possible antioxidant action. The application of GAGs in the sperm cryopreservation of fish is very recent, as the study by Pereira et al. (2020), who described promising results for the sperm conservation of tambaqui (Colossoma macropomum).

Thus, the objectives of the research were to evaluate the in vitro antioxidant action of GAGs, from the O. niloticus skin, and to determine their ideal concentration in the sperm freezing medium of $P$. brevis. 


\section{Materials and Methods}

Obtaining and analyzing physicochemical GAGs from O. niloticus skin

This research was approved by the Animal Ethics Committee of the State University of Ceará (UECE; protocol number, 09664402/2019).

Skin tissue samples of $O$. niloticus were obtained from specimens grown at the Fish Farming Station at the Federal University of Ceará, Brazil. The extraction of GAGs from the skin of $O$. niloticus was performed according to Salles et al. (2017) based on Farias, Valente, Pereira and Mourão (2000). Initially, $20 \mathrm{~g}$ of dehydrated skin were digested with $10 \%$ crude papain $\left(24 \mathrm{~h}, 60^{\circ} \mathrm{C}\right)$ in $200 \mathrm{~mL}$ of $100 \mathrm{mM}$ sodium acetate buffer, containing cysteine and EDTA, both at $5 \mathrm{mM}$. After incubation, the material was filtered through a nylon net and precipitated (72 h, room temperature) with 10 $\mathrm{mL}$ of $10 \%$ cetylpyridinium chloride (CPC). The precipitate (GAGs) was centrifuged $\left(9,560 \times g_{i}\right.$ $20^{\prime}, 25^{\circ} \mathrm{C}$ ) and washed with $100 \mathrm{~mL}$ of $0.05 \%$ $\mathrm{CPC}$ and centrifuged again $(9,560 \times \mathrm{g} ; 20$ ', 25 $\left.{ }^{\circ} \mathrm{C}\right)$. Then, the GAGs were dissolved for 20 ' in 50 $\mathrm{mL}$ of a $2 \mathrm{M} \mathrm{NaCl}$ : ethanol solution (100: 15, v: v) and precipitated with $100 \mathrm{~mL}$ of commercial ethanol $\left(4^{\circ} \mathrm{C}, 72 \mathrm{~h}\right)$. The obtained precipitate was centrifuged $\left(9,560 \times \mathrm{g} ; 20^{\prime}, 25^{\circ} \mathrm{C}\right)$ and washed twice with $100 \mathrm{~mL}$ of $80 \%$ ethanol and once with the same volume of commercial ethanol. After each centrifugation step, GAGs were dried in an air circulation oven $\left(60{ }^{\circ} \mathrm{C}\right.$; 6 h) and the yield (\%) was calculated based on the initial raw material $(n=3)$. The presence of GAGs $(12 \mu \mathrm{g})$ was checked by $0.5 \%$ agarose gel electrophoresis using treatment with toluidine blue or stains-all, comparing with chondroitin sulfate, dermatan sulfate and heparin standards, as described by Salles et al. (2017).

Experiment 1: Capacity of antioxidant in vitro activity of GAGs

\section{DPPH scavenging activity}

The evaluation of the ability of GAGs to reduce 1,1-diphenyl-2-picryl-hydrazil (DPPH) was performed according to Blois (1958), with some modifications. For this, different concentrations of GAGs ( 0.125 to $\left.4.0 \mathrm{mg} \mathrm{mL}^{-1}\right)$ were added to the methanol solution of DPPH (75 M). After 30', absorbance was measured at $517 \mathrm{~nm}$. All reactions were performed in triplicates and butylatedhydroxytoluene (BHT) was used as a control.

The DPPH scavenging activity was calculated using the following equation: scavenging activity $(\%)=[A 0-(A-A b) / A O]$ $\times 100$, where $A 0=D P P H$ without sample; $A$ = sample $+\mathrm{DPPH}$; and $A b=$ sample without $\mathrm{DPPH}$.

\section{Chelating ferrous ability}

The methodology of Chew, Lim, Omar and Khoo (2008) was used, with modifications. Different concentrations of GAGs (0.125 to 4.0 $\mathrm{mg} \mathrm{mL}^{-1}$ ) were added to ferrous sulfate (FeSO4; $0.1 \mathrm{mM}$ ) and ferrozine acid (3- (2-pyridyl) -5,6-diphenyl-1,2,4-triazine - $p$, p-disulfonic; $0.25 \mathrm{mM})$. The tubes were shaken (1'), incubated (10') and the absorbance measured at $562 \mathrm{~nm}$. All reactions were performed in triplicates and EDTA was used as a control.

Results are expressed as a percentage of chelating activity according to the following formula: Chelating activity $(\%)=[A O-(A-A b) /$ 
$\mathrm{AO}] \times 100$, where $\mathrm{A0}=\mathrm{FeSO}_{4}+$ Ferrozine without sample; $\mathrm{A}=$ sample $+\mathrm{FeSO}_{4}+$ Ferrozine; and $\mathrm{Ab}=$ sample without $\mathrm{FeSO}_{4}+$ Ferrozine .

\section{Total antioxidant capacity}

The total antioxidant capacity was performed by the formation of the phosphomolybdate complex, according to Prieto, Pineda and Aguilar (1999). GAGs (0.125 to $4.0 \mathrm{mg} \mathrm{mL}^{-1}$ ) were added to a solution containing ammonium molybdate (4 mM), sulfuric acid $(0.6 \mathrm{M})$, and sodium phosphate $(28 \mathrm{mM})$, and were incubated at $95^{\circ} \mathrm{C}\left(90^{\prime}\right)$. Absorbance was measured at $695 \mathrm{~nm}$.

All reactions were performed in triplicate and a $200 \mathrm{~g} \mathrm{~mL}^{-1}$ sample of ascorbic acid (AA) was used as a control and considered as $100 \%$ antioxidant activity. The results were expressed as a percentage of chelating activity using the following formula: Total antioxidant capacity $(\%)=\left[\left(A_{\text {sample }}-A_{\text {blank }}\right) /\left(A_{\text {ascorbicac }}-A_{\text {blank }}\right)\right]$ $\times 100$.

Experiment 2: Effect of freezing medium supplementation with GAGs on seminal cryopreservation of P. brevis

\section{Experimental animals and milt collection}

This experiment was performed in October 2019 in Fortaleza, Ceará, Brazil. Seventeen $P$. brevis males (weight: 147.14 $\pm 38.71 \mathrm{~g}$ and length: $17.76 \pm 5.58 \mathrm{~cm}$ ) were used in this experiment. They belong to the Laboratory of Biotechnology of Fish Reproduction (LBRP), located at the State University of Ceará, Fortaleza, Ceará, Brazil. Hormonal induction to reproduction and management to obtain milt from $P$. brevis were carried out according to standard laboratory procedures (Nunes et al., 2016; Nascimento et al., 2017). The doses of carp pituitary extract administered were 0.4 and $4.0 \mathrm{mg} \mathrm{kg}^{-1}$ of body weight.

\section{Analysis of fresh milt and pool formation}

Immediately after collection, sperm motility was determined through an objective analysis. For this, $1 \mu \mathrm{L}$ of milt was placed in a Makler chamber, activated with $100 \mu \mathrm{L}$ of $\mathrm{NaCl}$ (125 mM), and analyzed by Computer-Assisted Sperm Analysis (CASA), using the Sperm Class Analyzer software (SCA; Microptics ${ }^{\circledR}$; Barcelona, Espanha; Nunes et al., 2016). The fish configuration with 50 frames per second was used. Analyzes were performed in triplicate and approximately 15" after sperm activation (Pereira et al., 2020). Milt samples with motility above $80 \%$ were used to form pools ( $n=6)$, and each pool contained milt from four animals.

Subsequently, each pool was evaluated for membrane integrity, DNA integrity, concentration, morphology, and sperm kinetic (total motility [\%], curvilinear velocity [VCL $\mu \mathrm{m} \mathrm{s}^{-1}$ ], straight-line velocity [VSL $-\mu \mathrm{m} \mathrm{s}^{-1}$ ], and mean path velocity [VAP $\left.-\mu \mathrm{m} \mathrm{s}^{-1}\right]$ ).

Sperm concentration was measured by using a Neubauer chamber under an optical microscope (400x). For this analysis, fresh milt was fixed in a $4 \%$ formaldehyde citrate solution (1: 4000 - milt: 4\% formaldehyde citrate; Leite et al., 2013).

For sperm morphology analysis, sperm were fixed in $4 \%$ formaldehyde citrate solution (1: 100; sperm solution: fixative) and stained with Rose Bengal at a ratio of 1:10 (dye: fixed milt). Two slides per sample were prepared 
and 200 cells (100 spermatozoa per slide) were evaluated under an optical microscope (400x). Sperm morphological classification was performed based on Miliorini et al. (2011).

Sperm membrane integrity was assessed using the eosin-nigrosin staining method (Blom, 1950). A mixture of $5 \mu \mathrm{L}$ of milt, $10 \mu \mathrm{L}$ of eosin, and $10 \mu \mathrm{L}$ of nigrosin (1: 2: 2 ratio - milt: eosin: nigrosin) was smeared onto a microscope slide (one slide per sample), and 200 spermatozoa were analyzed under a light microscope $(400 \times)$. Cells were considered to have an intact membrane when they were colorless and a disrupted membrane when they were pink or red-stained.

The DNA integrity was evaluated by the fragmentation rate of sperm chromatin, performed by the SCD test (sperm chromatin dispersion), with adaptations (Fernandez et al., 2005). For this, 0.1 and $1 \mu \mathrm{L}$ of fresh and cryopreserved milt, respectively, were diluted in $1.5 \mathrm{~mL}$ phosphate-saline buffer (PBS) and kept in a water bath at $37^{\circ} \mathrm{C}$ until use. Then, $25 \mu \mathrm{L}$ of milt-PBS was mixed with $50 \mu \mathrm{L}$ of low molecular-weight agarose (Low Weight Agarose; Sigma-Aldrich, St Louis, MO USA) and $2 \mu \mathrm{L}$ aliquots of this mixture were deposited in each of the 10 points of a slide previously prepared with NA agarose (Agarose NA; Sigma-Aldrich, St Louis, MO, USA). After that, the slides were covered with coverslips and placed on a metal surface cooled to 4 ${ }^{\circ} \mathrm{C}$ for 5 '. Subsequently, the coverslips were removed and subjected to different solutions: acidic solution (seven minutes); lysis solution $\left(25^{\prime}\right)$; distilled water (five minutes); ethanol $70 \%$, $90 \%$, and $100 \%$, respectively (two minutes each). After the baths, the slides were dried at room temperature and stained with a Panotic kit (RenyLab Química e Farmaceutica LTDA,
Barbacena, MG, Brazil), dipping the slides in each dye for 10, 20, and 20", respectively. Finally, the slides were washed with distilled water and dried at room temperature. Two hundred sperm cells were evaluated using a phase-contrast optical microscope with an attached camera (200x; Nikon Eclipse 50 i, Tokyo, Japan) for the presence of a halo around the head of the sperm: cells with a halo indicate that there was a dispersion of the chromatin (intact DNA) and cells without a halo indicate fragmented DNA.

The analysis of the sperm kinetics of each pool was performed at CASA, as previously described for in natura milt.

\section{Milt freezing and thawing}

The pools ( $\mathrm{n}=6$ ) were diluted (1:9 - milt:diluent) and frozen in a solution containing $5 \%$ glucose and 10\% DMSO, which was supplemented or not with different concentrations of GAGs: 0 (control), 0.5, 1.0, $1.5,2.0,2.5,3.0,3.5,4.0,4.5$, and $5.0 \mathrm{mg} \mathrm{mL}-1$ (total 10 treatments).

For each treatment, the diluted milt was packed into two $0.25 \mathrm{~mL}$ French straws that were sealed with polyvinyl alcohol and left to equilibrate $\left(4^{\circ} \mathrm{C}, 10^{\prime}\right)$. Then, the straws were placed into the dry shipper, where they were frozen in nitrogen vapor $\left(-170^{\circ} \mathrm{C}\right)$ for $15^{\prime}$ and then stored in a liquid nitrogen canister $\left(-196{ }^{\circ} \mathrm{C}\right)$. After 15 days, the samples were thawed by immersion in a water bath at $30^{\circ} \mathrm{C}$ for 16" (Nunes et al., 2016). Finally, the thawed samples were evaluated for DNA integrity, membrane integrity, kinetics, and sperm morphology, following the same methodology that was previously described for fresh milt. 


\section{Statistical analyses}

Data were expressed as mean \pm standard deviation of the means and the level of significance considered for the two experiments was $\mathrm{P}<0.05$. In experiment 1 , the antioxidant effect was performed by analysis of variance (ANOVA) followed by the Student-Newman-Keuls test to compare the means and the Kruskal-Wallis non-parametric test followed by the Dunn test to compare medians. The software program GraphPad Prism (version 5.0.1, USA) was used.

In experiment 2, the effect of treatments on seminal cryopreservation was analyzed by the statistical software Statistical Analysis System Institute [SAS] (2002). The parameters of VCL and VAP were submitted to logarithmic transformation. The degree of association between the parameters analyzed and the different GAGs concentrations were examined by linear regression (PROC REG).

\section{Results and Discussion}

\section{GAGs performance and characteristics}

The samples of dehydrated skin of O. niloticus yielded $0.22 \pm 0.00 \%$ of GAGs. In the agarose analysis, after using toluidine blue, it revealed an electrophoretic profile of a single sulfated GAG co-migrating as a dermatan (Figure 1A). The gel only stained with stains-all indicated more intense banding and visualization patterns, in addition to the absence in the sample of hyaluronic acid (Figure 1B).

This analysis shows that the skin of $O$. niloticus has a low amount of GAGs after proteolytic digestion, as demonstrated for aquatic organisms (Valcarcel et al., 2017). It was also revealed, by electrophoresis, that the skin samples had GAGs dermatan and were free of hyaluronic acid, suggesting unique GAGs species in the examined tissue. These observations were in line with Salles et al. (2017), who previously analyzed O. niloticus skin GAGs.

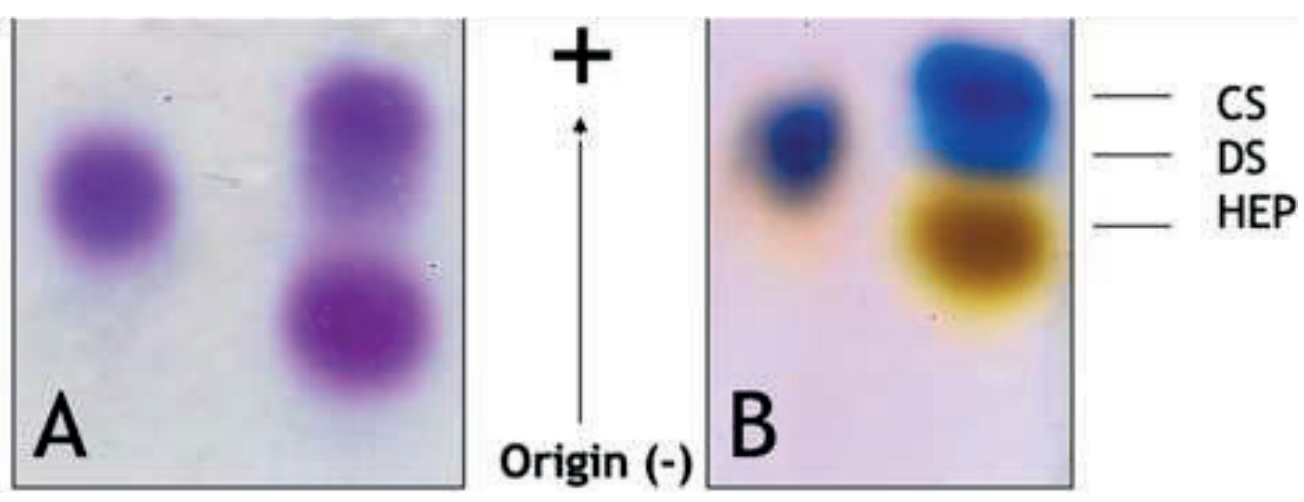

Figure 1. Agarose gel electrophoresis of Oreochromis niloticus skin glycosaminoglycans (GAGs) and standards GAGs chondroitin sulfate (CS), dermatan sulfate (DS), heparin (HEP) present on gels stained with $0.1 \%$ toluidine blue $(A)$ or stains all $(B)$. 


\section{O. niloticus skin GAGs possesses in vitro antioxidant effects}

O. niloticus skin GAGs presented an in vitro antioxidant action, reducing oxidative processes, depending on concentration, in all tests performed. In the DPPH test, GAGs were more effective at a concentration of 4.0 $\mathrm{mg} \mathrm{mL}^{-1}$ (30.26 $\left.\pm 2.80 \%\right)(\mathrm{P}<0.05$; Figure $2 \mathrm{~A})$. Meanwhile, at concentrations of 1.0, 2.0 and $4.0 \mathrm{mg} \mathrm{mL}^{-1}$, they exerted a greater chelating effect, whose inhibitions were $29.43 \pm 0.40 \%$, $32.22 \pm 0.10 \%$ and $31.10 \pm 0.59 \%$, respectively $(\mathrm{P}<0.05$; Figure 2B). GAGs showed total antioxidant capacity, due to the formation of complex phosphomolybdates, with a value of $25.21 \pm 0.64 \%$ at a concentration of $4 \mathrm{mg} \mathrm{mL}^{-1}$ ( $P<0.05$; Figure $2 \mathrm{C}$ ). For all tests, the reducing potential was lower than the controls $B H T$, EDTA, and AA, respectively $(P<0.05)$.

The imbalance of antioxidant systems leads to the production of ROS and free radicals, which induce oxidative reactions on biological molecules causing irreversible damage and cell injury (Pisoschi \& Pop, 2015). In the in vitro tests performed, GAGs from the skin of $O$. niloticus werer demonstrated to have an antioxidant effect, as they reduced oxidative reactions in a concentration- dependent manner. The preponderant effect on chelation suggested the greater affinity of active sites with iron, inhibiting the production of hydroxyl radicals in the system (Alencar et al., 2019). Therefore, the presence of sulfate radicals may be related to the chelation effect, sequestration or electron-donating ability of GAGs (Jridi et al., 2019). Thus, the antioxidant potential of sulfated polysaccharides varies with their origin (Bai et al., 2018; Alencar et al., 2019; Jridi et al., 2019).

\section{Effect of $O$. niloticus skin GAGs on the composition of the freezing medium}

In experiment 2, the collected milt was used to prepare six pools, which presented a mean sperm concentration of $18.65 \pm 0.28 \times$ $10^{9}$ spermatozoa per $\mathrm{mL}$ of milt; $92.83 \pm 3.62 \%$ intact membrane spermatozoa; $75.25 \pm 3.84 \%$ normal morphology; and $97.08 \pm 2.13 \%$ intact DNA. Regarding kinetic parameters, the total motility rate was $94.93 \pm 4.80 \%$; the mean VCL, VSL, and VAP were $85.80 \pm 15.52 \mu \mathrm{m} \mathrm{s}^{-1}$, $42.06 \pm 10.05 \mu \mathrm{m} \mathrm{s}^{-1}$, and $59.33 \pm 12.50 \mu \mathrm{m}$ $\mathrm{S}^{-1}$, respectively. The data found for fresh milt of $P$. brevis are similar to those in the literature (Lopes et al., 2014; Nunes et al., 2016). 


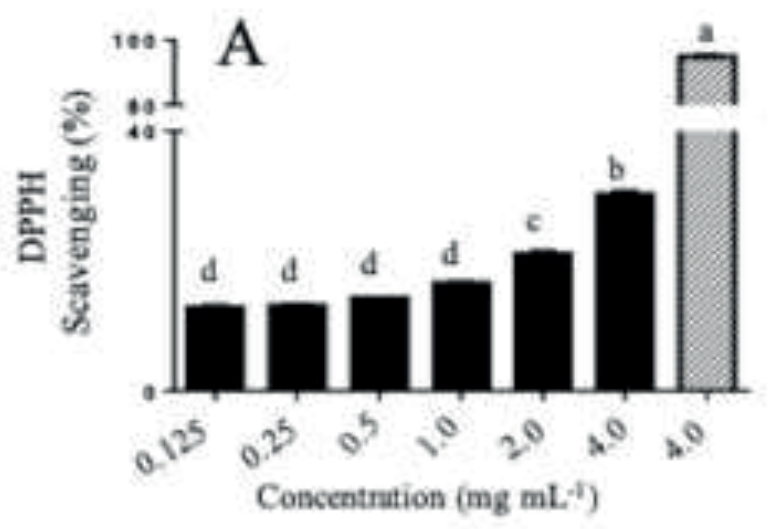

GAG

BHT

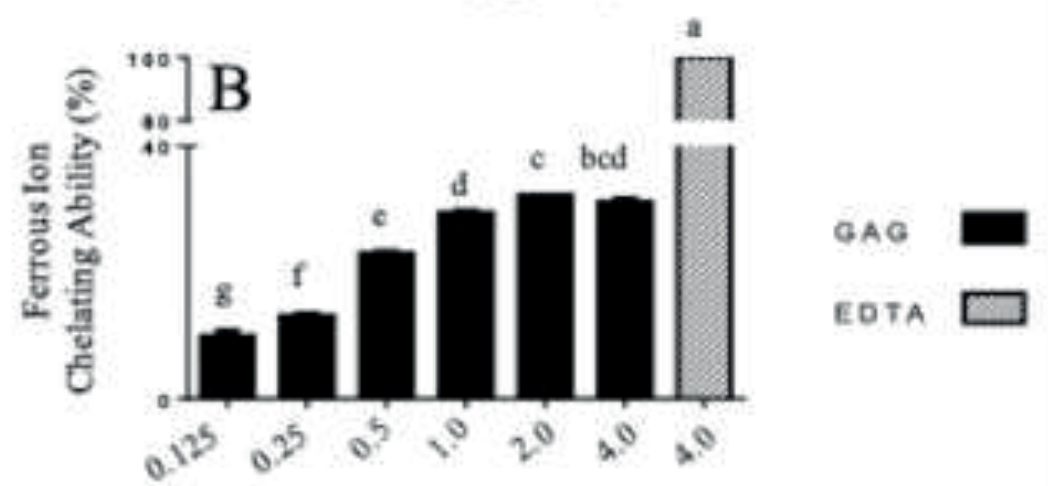

Concentration (mg $\mathrm{mL}^{-4}$ )

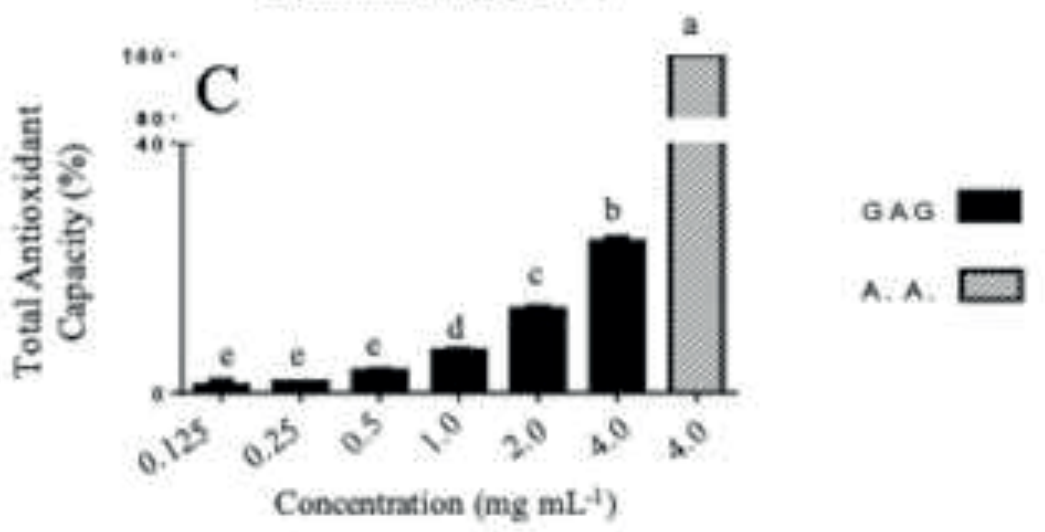

Figure 2. O. niloticus skin glycosaminoglycans (GAGs) has in vitro antioxidant capacity. (A) Scavenging 1,1-diphenyl-2- picrylhydrazyl (DPPH) radicals, (B) chelating ferrous ability, and (C) molybdate ion reduction assay. Columns with different letters are significantly different at $P \leq 0.05$.

The total motility rate of the control was $50.35 \pm 11.98 \%$, which was close to the results of concentrations $0.5 \mathrm{mg} \mathrm{mL}^{-1}$ and $1.0 \mathrm{mg} \mathrm{mL}^{-1}(47.75 \pm 10.63 \%$ and $46.70 \pm$ $7.01 \%$, respectively). However, from $3.0 \mathrm{mg}$
$\mathrm{mL}^{-1}(35.52 \pm 5.56 \%)$ to $5.0 \mathrm{mg} \mathrm{mL}^{-1}(30.80$ $\pm 5.24 \%$ ) a decline in the sperm motility rate was observed. The same pattern was followed by the VCL, VSL and VAP parameters. In this case, the control $\left(38.09 \pm 10.82 \mu \mathrm{m} \mathrm{s}^{-1} ; 18.60 \pm\right.$ 
$9.63 \mu \mathrm{m} \mathrm{s}^{-1}$ and $26.02 \pm 11.38 \mu \mathrm{m} \mathrm{s}^{-1}$ ) and the treatments with concentrations $0.5 \mathrm{mg} \mathrm{mL}^{-1}$ (34.95 $\pm 8.53 \mu \mathrm{m} \mathrm{s}^{-1} ; 16.13 \pm 7.11 \mu \mathrm{m} \mathrm{s}^{-1}$ and $23.78 \pm 6.89 \mu \mathrm{m} \mathrm{s}^{-1}$, respectively) and $1.0 \mathrm{mg}$ $\mathrm{mL}^{-1}\left(39.15 \pm 3.80 \mu \mathrm{ms}^{-1} ; 21.34 \pm 5.39 \mu \mathrm{ms}^{-1}\right.$ and $28.61 \pm 5.56 \mu \mathrm{m} \mathrm{s}^{-1}$, respectively) showed very similar results, while a motility decline is noted from $3.0 \mathrm{mg} \mathrm{mL}^{-1}\left(29.08 \pm 6.37 \mu \mathrm{m} \mathrm{s}^{-1} ; 10.80 \pm\right.$ $5.41 \mu \mathrm{m} \mathrm{s}^{-1} ; 16.91 \pm 6.31 \mu \mathrm{m} \mathrm{s}^{-1}$, respectively)

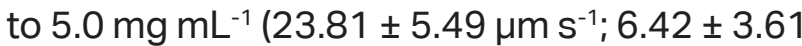
$\mu \mathrm{m} \mathrm{s}^{-1} ; 11.77 \pm 4.83 \mu \mathrm{m} \mathrm{s}^{-1}$, respectively). Thus, a negative relation was observed between the sperm kinetics parameters and the increasing on GAGs concentrations (Table 1; Figure 3).
Donnelly, McClure and Lewis (1999) observed that high concentrations of antioxidant substances in the freezing medium might trigger a proactive effect, generating more free radicals. This has been demonstrated in sperm cryopreservation studies of gilthead seabream (Sparus aurata) and European seabass (Dicentrarchus labrax) using high concentrations of ascorbic acid and $\alpha$-tocopherol (Cabrita et al., 2011). Thus, we assume that the decline in P. brevis sperm kinetics may be related to high GAGs (extracted from O. niloticus skin) concentrations.

\section{Table 1}

Straight-line velocity (VSL - $\mu \mathrm{m} \mathrm{s}^{-1}$ ) and average path velocity (VAP - $\mu \mathrm{m} \mathrm{s}^{-1}$ ) of $P$. brevis sperm cryopreserved in freezing medium supplemented with $O$. niloticus skin glycosaminoglycans (GAGs) at different concentrations ( $n=6$ pools)

$\begin{array}{ccc}\text { GAGs Concentration }\left(\mathrm{mg} \mathrm{mL}^{-1}\right) & \text { VSL }\left(\mu \mathrm{m} \mathrm{s}^{-1}\right) & \text { VAP }\left(\mu \mathrm{m} \mathrm{s}^{-1}\right) \\ 0 & 18.60 \pm 9.63 & 26.02 \pm 11.38 \\ 0.5 & 16.13 \pm 7.11 & 23.78 \pm 6.89 \\ 1.0 & 21.34 \pm 5.39 & 28.61 \pm 5.56 \\ 1.5 & 19.03 \pm 7.86 & 26.26 \pm 8.94 \\ 2.0 & 11.50 \pm 7.34 & 17.16 \pm 8.56 \\ 2.5 & 16.78 \pm 5.43 & 23.45 \pm 5.80 \\ 3.0 & 10.80 \pm 5.41 & 16.91 \pm 6.31 \\ 3.5 & 13.47 \pm 2.07 & 19.69 \pm 2.14 \\ 4.0 & 8.50 \pm 1.86 & 14.22 \pm 1.75 \\ 4.5 & 10.62 \pm 3.75 & 16.10 \pm 3.99 \\ 5.0 & 6.42 \pm 3.61 & 11.77 \pm 4.83 \\ P & 0.05 & 0.01 \\ \text { R-Square } & 0.33 & 0.29 \\ \text { Equation } & \mathrm{Y}=4.5-0.3(\mathrm{x}) & \mathrm{Y}=1.4-0.1{ }^{*}(\mathrm{x})\end{array}$

Data are expressed as mean \pm standard deviation (SD). Statistical significance at $\mathrm{P}<0.05$. 

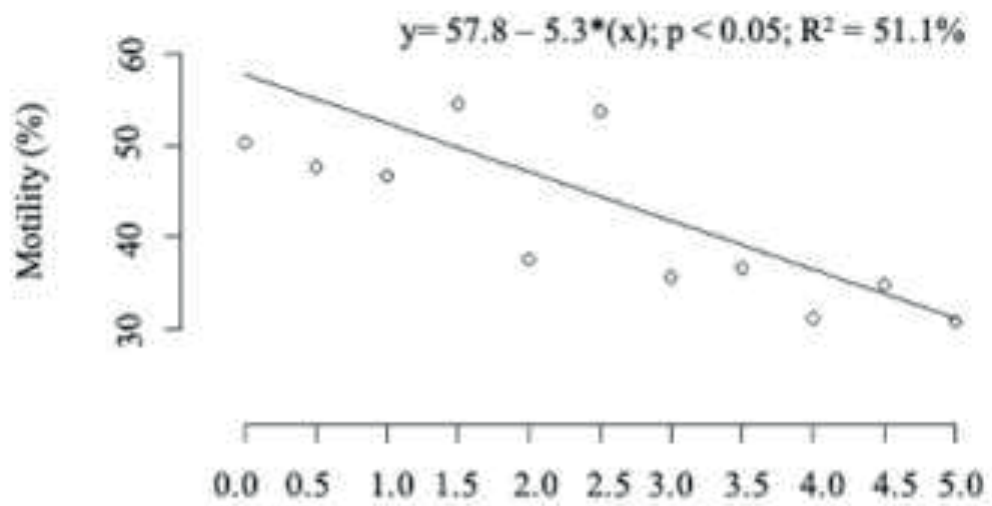

GAG Concentration (mg mL-1)

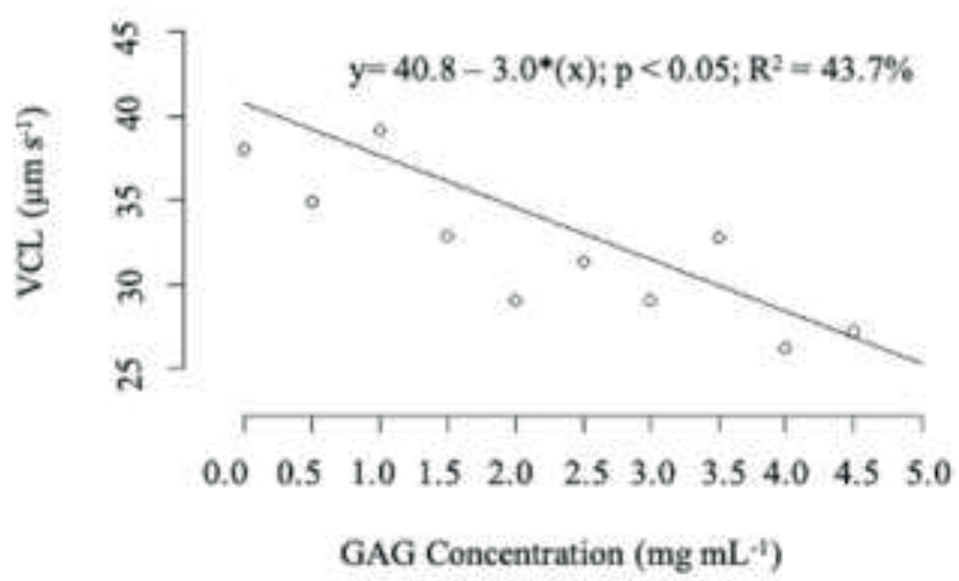

Figure 3. Influence of glycosaminoglycans (GAGs) concentrations on total motility (\%) and curvilinear velocity $\left(\mathrm{VCL}-\mu \mathrm{m} \mathrm{s}^{-1}\right)$ of cryopreserved $P$. brevis sperm ( $\mathrm{n}=6$ pools).

However, supplementation of the freezing medium with antioxidant agents is indicated, since cryopreservation may modify the sperm's natural antioxidants activity. It is proven that this technique can decrease catalase activity; however, the addition of antioxidants ( $\alpha$-tocopherol and ascorbic acid) can normalize the action of this enzyme (Figueroa et al., 2018; Chen et al., 2010; Lahnsteiner, Mansour, \& Kunz, 2011). MartínezPáramo et al. (2012) stated that the addition of $\alpha$-tocopherol and ascorbic acid was not able to improve the sperm kinetics parameters of Dicentrarchus labrax, but these antioxidants neutralized the oxidative stress caused by cryopreservation. Likewise, in the present study, the lowest concentration of GAGs from the $O$. niloticus skin did not improve the kinetic parameters, but it may have been relevant, since it was not toxic to the cells, as the result was similar to the control.

In recent years, studies have been carried out on the addition of antioxidant agents to the sperm freezing medium of fishes, demonstrating that their effect might be species-specific and dependent on their characteristics and concentration (Cabrita et 
al., 2011). For Cyprinus carpio, the addition of $20 \mathrm{mmol} \mathrm{L}^{-1}$ of cysteine increased the rate and duration of cryopreserved sperm motility, when compared to lower concentrations $\left(2.5,5\right.$, and $\left.10 \mathrm{mmol} \mathrm{L}^{-1}\right)$ (Öğretmen, İnanan, Kutluyer, \& Kayim, 2015). Taurine at a concentration of $1 \mathrm{mmol} \mathrm{L}^{-1}$ increased sperm motility and stability of the spermatic DNA of Sparus aurata when compared to $10 \mathrm{mmol} \mathrm{L}^{-1}$ (Cabrita et al., 2011). For the fertilization rate of Salvelinus fontinalis, catalase, when added to the freezing medium at a concentration of 100 $U L^{-1}$, showed superior results when compared to the concentration of $200 \mathrm{U} \mathrm{L}^{-1}$ and even to other antioxidants (Lahnsteiner et al., 2011). In the present study, we tested different GAGs concentrations, and the lowest one presented the best results. However, we believe that new research needs to be carried out by testing even lower concentrations.

Sperm cryopreservation can cause physiological and structural changes (Figueroa et al., 2016). Another assumption about the decline in sperm kinetics is that perhaps that is related to mitochondria damage, which is a key organelle for energy production (Figueroa et al., 2016). The partial loss of mitochondria results in reduced movement of the sperm flagellum, as well as the loss of progressive motility (Zhang et al., 2003). The functionality of this organelle is preponderant for motility and the fertilizing capacity of sperm (Figueroa et al., 2016). Thus, research is needed to carry out analyses, including ultrastructural ones, of the mitochondria of post-thawed sperm cells of $P$. brevis, as well as their fertilizing capacity.
The use of sulfated GAGs in the freezing medium is recent; however, hyaluronic acid, a non-sulfated GAGs with antioxidant properties (Mendoza et al., 2009), was used as a supplement to mammalian sperm freezing medium. Results indicate that hyaluronic acid showed a protective effect on the thawed milt of boars (Qian, Yu, \& Zhou, 2016), while for rams, it was not effective (Najafi et al., 2014). These GAGs are fundamental for the sperm functions of mammals (Suzuki, Eriksson, Shimizu, Nagai, \& Rodriguez-Martinez, 2000), but for fish sperm, whose fertilization mechanism is different, little is known (Browne et al., 2015).

In the present study, it was observed no relation of membrane integrity with the increase of GAGs concentration, since the mean of sperm with an intact membrane of the control was $78.0 \pm 1.06 \%$, while the one of the highest GAGs concentration $\left(5.0 \mathrm{mg} \mathrm{mL}^{-1}\right)$ was $69.33 \pm 1.69 \%(P>0.05$; Table 2$)$. Pereira et al. (2020) observed good results of sperm membrane integrity when adding GAGs from the skin of $O$. niloticus to the sperm freezing medium of tambaqui (C. macropomum). In addition, unpublished studies suggest that these GAGs also promote a protective effect on the plasma membrane of $P$. brevis sperm submitted to vitrification. Other studies on antioxidants, also found an improvement in this parameter when ascorbic acid and $\alpha$-tocopherol were added to the seminal freezing medium of Salmo salar (Figueroa et al., 2018). 


\section{Table 2}

Membrane integrity, DNA integrity and normal morphology of $P$. brevis sperm cryopreserved in freezing medium supplemented with $O$. niloticus skin glycosaminoglycans (GAGs) at different concentrations ( $n$ $=6$ pools)

\begin{tabular}{cccc|}
$\begin{array}{c}\text { GAGs Concentration } \\
\left(\mathrm{mg} \mathrm{mL}^{-1}\right)\end{array}$ & $\begin{array}{c}\text { Membrane Integrity } \\
(\%)\end{array}$ & $\begin{array}{c}\text { Normal Sperm } \\
\text { Morphology }(\%)\end{array}$ & $\begin{array}{c}\text { DNA } \\
\text { Integrity (\%) }\end{array}$ \\
0 & $78.0 \pm 1.06$ & $79.25 \pm 0.92$ & $89.12 \pm 1.67$ \\
0.5 & $64.83 \pm 4.45$ & $75.90 \pm 1.49$ & $87.10 \pm 0.79$ \\
1.0 & $65.40 \pm 3.44$ & $74.70 \pm 1.49$ & $89.90 \pm 1.56$ \\
1.5 & $70.40 \pm 2.62$ & $76.80 \pm 1.30$ & $91.70 \pm 1.60$ \\
2.0 & $66.40 \pm 3.85$ & $75.80 \pm 1.94$ & $88.12 \pm 4.34$ \\
2.5 & $65.66 \pm 4.93$ & $77.66 \pm 1.49$ & $87.33 \pm 2.21$ \\
3.0 & $65.50 \pm 2.42$ & $75.00 \pm 1.75$ & $88.70 \pm 3.95$ \\
3.5 & $71.83 \pm 1.92$ & $77.33 \pm 0.90$ & $85.10 \pm 3.26$ \\
4.0 & $69.87 \pm 2.93$ & $70.87 \pm 1.39$ & $85.62 \pm 2.05$ \\
4.5 & $71.33 \pm 1.94$ & $75.08 \pm 1.45$ & $87.75 \pm 3.05$ \\
5.0 & $69.33 \pm 1.69$ & $75.33 \pm 1.99$ & $89.80 \pm 2.91$ \\
P-valor & 0.9590 & 0.2987 & 0.2224 \\
Equation & $\mathrm{Y}=69.44$ & $\mathrm{Y}=77.28$ & $\mathrm{Y}=90.06$ \\
\hline
\end{tabular}

Data are expressed as mean \pm standard deviation (SD). Statistical significance at $\mathrm{P}<0.05$.

Sulfated polysaccharides are generally non-toxic to cells of various biological systems, probably because they reduce ROS that lead to oxidative stress and causes disease (Alencar et al., 2019; Jridi et al., 2019). Thus, adding substances with antioxidant action to the freezing medium is important, since the sperm plasma membrane is susceptible to lipid peroxidation during the cryopreservation process. Pereira et al. (2020) reported that GAGs from $O$. niloticus skin protect the plasma membrane of $C$. macropomum sperm. The same was observed in the present study, as the GAGs did not impair the membrane integrity of $P$. brevis in any tested concentration.

For morphology, no relation was found with the increase of GAGs concentrations $(P>$ 0.05; Table 2). The control (un-supplemented) showed $79.25 \pm 0.92 \%$ of sperm with normal morphology, while the highest GAGs concentration resulted in $75.33 \pm 1.99 \%$. Artificial fertilization of fish requires a high proportion of spermatozoa per oocyte in a small and controlled environment, and in this case, up to $50 \%$ of sperm abnormalities are acceptable (Miliorini et al., 2011). In addition, in this study, the most common sperm defect was the bent tail, which can affect progressive sperm motility. However, according to Miliorini et al. (2011), the morphopathologies that most affect sperm motility and fertilization rate are strongly coiled tail and tail stump.

There is a strong correlation between increases in sperm abnormalities and the reduction in sperm motility (B. B. Costa, Marques, Lassen, Rodrigues, \& Streit, 2019). 
However, in the present study, the sperm abnormalities rate remained constant with the decrease in the motility rate. We assume that the high viscosity of the freezing medium, observed in those with higher GAGs concentrations, may have negatively affected sperm movement fluidity. High viscosity is a natural feature of alpaca milt, which has high GAGs concentrations and hinders interactions between the freezing medium and the cell membrane (Kershaw-Young, Stuart, Evans, \& Maxwell, 2013). As in alpacas, we also believe that the presence of GAGs, in high concentrations, may have hindered some cytoplasmic events in the P. brevis sperm cell before and/or after cryopreservation.

Regarding DNA integrity, there was no relationship between this parameter and the presence of GAGs ( $P>0.05$; Table 2). The control presented a mean $89.12 \pm 1.67 \%$ intact DNA, while the highest concentration tested $(5.0 \mathrm{mg}$ $\mathrm{mL}^{-1}$ ) showed $89.80 \pm 2.91 \%$ intact DNA. Sperm quality and DNA integrity are fundamental parameters for the survival and development of fish embryos (Figueroa et al., 2018). Studies have shown that the ideal scenario to fertilize fish oocytes is by using sperm with a maximum of $10 \%$ fragmented DNA, because, within this range, the female gamete can repair damaged DNA and generate viable embryos and larvae (Fernández-Díez et al., 2015; Fernández-Díez, González-Rojo, Lombó, \& Herraez, 2016). Pérez-Cerezales, Martínez-Paramo, Beirão and Herraez (2010) report Oncorhynchus mykiss larval survival rate greater than $60 \%$ when oocytes were fertilized using sperm with DNA integrity rate greater than $90 \%$. In the present study, approximately $10 \%$ fragmented DNA was observed in all tested GAGs concentrations, which is within the range recommended by the literature.
$P$. brevis milt can behave in different ways when frozen or cooled and be affected by the diluent or cryoprotectant used (Nascimento et al., 2017; Nunes et al., 2016; Lopes et al., 2014). Furthermore, in recent research, depending on the type of storage (cooled or frozen), the sperm activation medium can be a crucial point to achieve better results (Ferreira, 2019).

Taking into account the results of the present research, we believe that the lower concentration $\left(0.5 \mathrm{mg} \mathrm{mL}^{-1}\right)$ of GAGs from $O$. niloticus skin is an option for the $P$. brevis sperm cryopreservation. Although the results of this concentration use are not greater than the control group, the employment of antioxidant substances is justified since it can assist sperm cell maintenance and also neutralize possible oxidative effects triggered by the cryopreservation process. In this study, the crude GAGs extract from $\mathrm{O}$. niloticus skin was used, and we suggest the employment of fractions (a compound with a lower degree of chemical complexity obtained from the crude extract; Salles et al., 2017), to reduce the freezing medium viscosity of higher concentrations, to maintain or increase the $P$. brevis sperm kinetics.

As this is a pioneering study, and because there are few reports in the literature on the use of $O$. niloticus skin GAGs, we suggest that further research should be carried out to test longer sample storage times and to evaluate the interaction of GAGs with other diluents, such as powdered coconut water, specific to fish (ACP-104). ACP-104 has already been successful in freezing, cooling, and vitrification of $P$. brevis milt (Nascimento et al., 2017; Almeida-Monteiro et al., 2020). In addition, it is also relevant to use GAGs in other seminal conservation methods, such 
as cooling and vitrification, and to perform other analyses, such as mitochondrial activity, fertilization assay, and antioxidant activity. The study brings a new perspective on the applicability of GAGs from $O$. niloticus residues as a supplement to the sperm freezing medium of endangered native fish.

\section{Conclusions}

GAGs, extracted from O. niloticus skin, have antioxidant action and the concentration of $0.5 \mathrm{mg} \mathrm{mL}^{-1}$ was the most suitable to supplement the sperm freezing medium of $P$. brevis.

\section{Acknowledgment}

The authors of the current study are grateful to the Cearense Foundation for Technological Development Support (FUNCAP) and the Co-ordination for the Improvement of Higher Education Personnel (CAPES). We thank fish-farming station at the Federal University of Ceará.

\section{References}

Alencar, P. O. C., Lima, G. C., Barros, F. C. N., Costa, L. E. C., Ribeiro, C. V. P. E., Sousa, W. M.,... Freitas, A. L. P. (2019). A novel antioxidant sulfated polysaccharide from the algae Gracilaria caudata: In vitro and in vivo activities. Food Hydrocolloids, 90, 2834. doi: 10.1016/j.foodhyd.2018.12.007

Almeida-Monteiro, P. S., Oliveira-Araújo, M. S., Pinheiro, R. R. R., Lopes, J. T., Ferreira, Y. M., Montenegro, A. R.,... Salmito-Vanderley, C.
S. B. (2017). Influence of vitamins C and $E$ on the quality of cryopreserved semen Prochilodus brevis (Prochilodontidae, Teleostei). Semina: Ciências Agrárias, 38(4), 2669-2679. doi: 10.5433/1679-03 59.2017v38n4Supl1p2669

Almeida-Monteiro, P. S., Pinheiro, R. R. R., Oliveira-Araújo, M. S., Sales, Y. S., Nascimento, R. V., Nunes, L. T.,... SalmitoVanderley, C. S. B. (2020). Sperm vitrification of Prochilodus brevis using Powder Coconut Water (ACP-104) in association with different cryoprotectant concentrations. Aquaculture Research, 51(11), 4565-4574. doi: 10.1111/are.14 802

Bai, M., Han, W., Zhao, X., Wang, Q., Gao, Y., \& Deng, S. (2018). Glycosaminoglycans from a sea snake (Lapemis curtus): extraction, structural characterization and antioxidant activity. Marine Drugs, 16(5), 170. doi: 10.3390/md16050170

Blois, M. S. (1958). Antioxidant determinations by the use of a stable free radical. Nature, 181(4617), 1199-1200. doi: 10.1038/18 $11199 a 0$

Blom, E. (1950). A one-minute live-dead sperm stain by means of eosin-nigrosin. Fertility and Sterility, 1(2), 176-177. doi: 10.1016/ s0015-0282(16)30125-x

Bomfim, A. C., Peretti, D., Camillo, C. S., Costa, S. A. G. L., \& Nascimento, R. S. S. (2015). Reproductive biology and variations in the gonadal development of the fish Curimatã (Prochilodus brevis Steindachner, 1875) in captivity. Biota Amazônia, 5(2), 65-70. doi: 10.18561/2179-5746/biotaamazonia. v5n2p65-70 
Browne, R. K., Kaurova, S. A., Uteshev, V. K., Shishova, N. V., McGinnity, D., Figiel, C. R.,... Cosson J. (2015). Sperm motility of externally fertilizing fish and amphibians. Theriogenology, 83(1), 1-13. doi: 10.10 16/j.theriogenology.2014.09.018

Cabrita, E., Ma, S., Diogo, P., Martínez-Páramo, S., Sarasquete, C., \& Dinis, M. T. (2011). The influence of certain aminoacids and vitamins on post-thaw fish sperm motility, viability and DNA fragmentation. Animal Reproduction Science, 125(1-4), 189-195. doi: 10.1016/j.anireprosci.2011.03.003

Chen, Y. K., Liu, Q. H., Li, J., Xiao, Z. Z., Xu, S. H., Shi, X. H., \& Ma, D. Y. (2010). Effect of longterm cryopreservation on physiological characteristics, antioxidant activities and lipid peroxidation of red seabream (Pagrus major) sperm. Cryobiology, 61(2), 189193. doi: 10.1016/j.cryobiol.2010.07.003

Chew, Y. L., Lim, Y. Y., Omar, M., \& Khoo, K. S. (2008). Antioxidant activity of three edible seaweeds from two areas in South East Asia. LWT-Food Science and Technology, 41(6), 1067-1072. doi: 10.1016/j.Iwt.2007. 06.013

Costa, B. B., Marques, L. S., Lassen, P. G., Rodrigues, R. B., \& Streit, D. P. (2019). Cryopreservation-induced morphological changes in the sperm of South American silver catfish (Rhamdia quelen). Journal of Applied Ichthyology, 35(4), 987-993. doi: 10.1111/jai.13928

Costa, L. S., Fidelis, G. P., Cordeiro, S. L., Oliveira, R. M., Sabry, D. D. A., Câmara, R. B. G.,... Rocha, H. A. O. (2010). Biological activities of sulfated polysaccharides from tropical seaweeds. Biomedicine \& Pharmacotherapy, 64(1), 21-28. doi: 10. 1016/j.biopha.2009.03.005
Costa, R. B., Carvalho, M. A. M., Abreu, K. L., Vidal, D. L., Sales, R. O., Maggioni, R.,... Farias, J. O. (2015). Criação da curimatã comum, Prochilodus cearaensis Steindachner, 1911, em tanque rede. Revista Brasileira de Higiene e Sanidade Animal, 9(3), 482492. doi: 10.5935/1981-2965.20150044

Donnelly, E. T., McClure, N., \& Lewis, S. E. M. (1999). Antioxidant supplementation in vitro does not improve human sperm motility. Fertility and Sterility, 72(3), 484495. doi: 10.1016/s0015-0282(99)002 $67-8$

Farias, W. R., Valente, A. P., Pereira, M. S., \& Mourão, P. A. (2000). Structure and anticoagulant activity of sulfated galactans isolation of a unique sulfated galactan from the red algae Botryocladia occidentalis and comparison of its anticoagulant action with that of sulfated galactans from invertebrates. Journal of Biological Chemistry, 275(38), 2929929307. doi: 10.1074/jbc.M002422200

Fernandez, J. L., Muriel, L., Goyanes, V., Segrelles, E., Gosálvez, J., Enciso, M.,... Jonge, C. (2005). Simple determination of human sperm DNA fragmentation with an improved sperm chromatin dispersion test. Fertility and Sterility, 84(4), 833-842. doi: 10.1016/j.fertnstert.2004.11.089

Fernández-Díez, C., González-Rojo, S., Lombó, M., \& Herraez, M. P. (2016). Impact of sperm DNA damage and oocyterepairing capacity on trout development. Reproduction, 152(1), 57-67. doi: 10.1530/ rep-16-0077

Fernández-Díez, C., González-Rojo, S., Montfort, J., Cam, A. L., Bobe, J., Robles, V.,... Herráez, M. P. (2015). Inhibition of zygotic DNA repair:transcriptomeanalysis 
of the offspring in trout (Oncorhynchus mykiss). Reproduction, 149(1), 101-111. doi: 10.1530/REP-14-0382

Ferreira, Y. M. (2019). Efeito da osmolalidade de diferentes soluções ativadoras sobre a cinética espermática do sêmen fresco, resfriado e descongelado de Prochilodus brevis (Actinopterygii:Proc hilodontidae). Dissertação de mestrado, Universidade Estadual do Ceará, Fortaleza, CE, Brasil. Recuperado de http://www.uece.br/ppgcv/wp-content/ uploads/sites/6/2020/01/YasmimMaia_ Dissertação.pdf

Figueroa, E., Farias, J. G., Lee-Estevez, M., Valdebenito, I., Risopatrón, J., Magnotti, C.,... Oliveira, R. P. S. (2018). Sperm cryopreservation with supplementation of $\alpha$-tocopherol and ascorbic acid in freezing media increase sperm function and fertility rate in Atlantic salmon (Salmo salar). Aquaculture, 493, 1-8. doi: 10.1016/j.aquaculture.2018.04.046

Figueroa, E., Valdebenito, I., Merino, O., Ubilla, A., Risopatrón, J., \& Farias, J. G. (2016). Cryopreservation of Atlantic salmon Salmo salar sperm: effects on sperm physiology. Journal of Fish Biology, 89(3), 1537-1550. doi: 10.1111/jfb.13052

Food and Agriculture Organization of the United Nations (2018). The State of World Fisheries and Aquaculture. Retrieved from http://www.fao.org/3/i9540en/i9540en. pdf

Gurgel, L. D. L., Verani, J. R., \& Chellappa, S. (2012). Reproductive ecology of Prochilodus brevis an endemic fish from the semiarid region of Brazil. The Scientific World Journal, 2012, 1-7. doi: 10.1100/ 2012/810532
Jridi, M., Nasri, R., Marzougui, Z., Abdelhedi, O., Hamdi, M., \& Nasri, M. (2019). Characterization and assessment of antioxidant and antibacterial activities of sulfated polysaccharides extracted from cuttlefish skin and muscle. International Journal of Biological Macromolecules, 123, 1221-1228. doi: 10.1016/j.jjbiomac. 2018.11.170

Kershaw-Young, C. M., Stuart, C., Evans, G., \& Maxwell, W. M. C. (2013). The effect of glycosaminoglycan enzymes and proteases on the viscosity of alpaca seminal plasma and sperm function. Animal Reproduction Science, 138(3-4), 261-267. doi: 10.1016/j.anireprosci.2013. 02.005

Lahnsteiner, F., Mansour, N., \& Kunz, F. A. (2011). The effect of antioxidants on the quality of cryopreserved semenintwo salmonidfish, the brook trout (Salvelinus fontinalis) and the rainbow trout (Oncorhynchus mykiss). Theriogenology, 76(5), 882-890. doi: 10. 1016/j.theriogenology.2011.04.019

Leite, L. V., Melo, M. A. P., Oliveira, F. C. E., Pinheiro, J. P. S., Campello, C. C., Nunes, J. F., \& Salmito-Vanderley, C. S. B. (2013). Determinação da dose inseminante e embriogênese na fertilização artificial de tambaqui (Colossoma macropomum). Arquivo Brasileiro de Medicina Veterinária e Zootecnia, 65(2), 421-429. doi: 10.1590/ S0102-09352013000200018

Lopes, J. T., Pinheiro, J. P. S., Nunes, L. T., Pinheiro, R. R. R., Souza, M. E. M., Almeida, P. S.,... Salmito-Vanderley, C. S. B. (2014). Avaliação de diferentes crioprotetores e taxas de diluição na criopreservação seminal de Prochilodus brevis. Revista Brasileira de Reprodução Animal, 38(3), 170-175. 
Martínez-Páramo, S., Diogo, P., Dinis, M. T., Herráez, M. P., Sarasquete, C., \& Cabrita, E. (2012). Incorporation of ascorbic acid and a-tocopherol to the extender media to enhance antioxidant system of cryopreserved seabass sperm. Theriogenology, 77(6), 1129-1136. doi: 10.1016/j.theriogenology.2011.10.017

Mendoza, G., Prieto, J., Real, R., Perez, M., Merino, G., \& Alvarez, A. (2009). Antioxidant profile of hyaluronan: physico-chemical features and its role in pathologies. Mini Reviews in Medicinal Chemistry, 9(13), 1479-1488. doi: $10.2174 / 138955709790361494$

Miliorini, A. B., Murgas, L. D. S., Rosa, P. V., Oberlender, G., Pereira, G. J. M., \& Costa, D. V. (2011). A morphological classification proposalforcurimba(Prochiloduslineatus) sperm damages after cryopreservation. Aquaculture Research, 42(2), 177-187. doi: 10.1111/j.1365-2109.2010.02575.x

Najafi, A., Najafi, M., Zanganeh, Z., Sharafi, M., Martinez-Pastor, F., \& Adeldust, H. (2014). Cryopreservation of ram semen in extenders containing soybean lecithin as cryoprotectant and hyaluronic acid as antioxidant. Reproduction in Domestic Animals, 49(6), 934-940. doi: 10.1111/rda. 12405

Nascimento, R. V., Leite-Castro, L. V., Montenegro, A. R., Oliveira-Araújo, M. S., Lopes, J. T., Almeida-Monteiro, P. S.,... Salmito-Vanderley, C. S. B. (2017). Influence of cooling time and diluents on the freezability of Prochilodus brevis semen. Acta Scientiae Veterinariae, 45(1), 1-9. doi: 10.22456/1679-9216.80488

Nunes, L. T., Oliveira, M. S., Lopes, J. T., Souza, M. E. M., Pinheiro, R. R. R., Campello, C. C., \& Salmito-Vanderley, C. S. B. (2016).
Cryopreservation of Prochilodus brevis semen: freezing media and thawing rates. Semina: Ciências Agrárias, 37(3), 16431654. doi: 10.5433/1679-0359.2016v37 n3p1643

Nunes, L. T., Oliveira-Araújo, M. S., Lopes, J. T., Almeida-Monteiro, P. S., Nascimento, R. V., Pereira, V. A.,... Salmito-Vanderley, C. S. B. (2019). Fertilizing capacity of the cryopreserved sperm of Prochilodus brevis. Acta Scientiae Veterinariae, 47(1), 1-6. doi: 10.22456/1679-9216.92791

Öğretmen, F., İnanan, B. E., Kutluyer, F., \& Kayim, M. (2015). Effect of semen extender supplementation with cysteine on postthaw sperm quality, DNA damage, and fertilizing ability in the common carp (Cyprinus carpio). Theriogenology, 83(9), 1548-1552. doi: 10.1016/j.therio genology.2015.02.001

Pereira, V. A., Alencar, D. B., Araújo, I. W. F., Rodrigues, J. A. G., Lopes, J. T., Nunes, L. T.,... Salmito-Vanderley, C. S. B. (2020). Supplementation of cryodiluent media with seaweed or Nile tilapia skin sulfated polysaccharides for freezing of Colossoma macropomum (Characiformes: Serrasalmidae) semen. Aquaculture, 528, 1-6. doi: 10.1016/j.aqua culture.2020.735553

Pérez-Cerezales, S., Martínez-Paramo, S., Beirão J., \&Herraez, M. P. (2010). Evaluation of DNA damage as a quality marker for rainbow trout sperm cryopreservation and use of LDL as cryoprotectant. Theriogenology, 74(2), 282-289. doi: 10. 1016/j.theriogenology.2010.02.012

Pinheiro, J. P. S., Melo-Maciel, M. A. P., Linhares, F. R. A., Lopes, J. T., Almeida-Monteiro, P. S., Pinheiro, R. R. R., \& Salmito-Vanderley, 
C. S. B. (2016). Use of glucose or BTS ${ }^{\mathrm{TM}}$ combined with DMSO or methylglycol under two different freezing protocols for the cryopreservation of sperm from the common curimatã (Prochilodus brevis). Animal Reproduction, 13(4), 779-786. doi: 10.21451/1984-3143-AR782

Pisoschi, A. M., \& Pop, A. (2015). The role of antioxidants in the chemistry of oxidative stress: a review. European Journal of Medicinal Chemistry, 97, 55-74. doi: 10. 1016/j.ejmech.2015.04.040

Prieto, P., Pineda, M., \& Aguilar, M. (1999). Spectrophotometric quantitation of antioxidant capacity through the formation of a phosphomolybdenum complex: specific application to the determination of vitamin E. Analytical Biochemistry, 269(2), 337-341. doi: 10.10 06/abio.1999.4019

Qian, L., Yu, S., \& Zhou, Y. (2016). Protective effect of hyaluronic acid on cryopreserved boar sperm. International Journal of Biological Macromolecules, 87, 287-289. doi: 10.1016/j.ijbiomac.2016.02.075

Salles, T. C., Rodrigues, J. A. G., Barcellos, P. G., Amaral, G. F., Araújo, I. W. F., \& Mourão, P. A. S. (2017). Inhibition of thrombin generation by dermatan sulfate isolated from the skin of Oreochromis niloticus. Revista Brasileira de Ciências Agrárias, 12(1), 98104. doi: 10.5039/agraria.v12i1a5412

Shaliutina-Kolešová, A., Gazo, I., Cosson, J., \& Linhart, O. (2013). Comparison of oxidant and antioxidant status of seminal plasma and spermatozoa of several fish species. Czech Journal of Animal Science, 58(7), 313-320. doi: 10.17221/6861-cjas
Statistical Analysis System Institute (2202). SAS Institute. Statistical Analysis System user'sguide. Version 9.0 ed. Cary: SAS Institute, USA.

Suzuki, K., Eriksson, B., Shimizu, H., Nagai, T., \& Rodriguez-Martinez, H. (2000). Effect of hyaluronan on monospermic penetration of porcine oocytes fertilized in vitro. International Journal of Andrology, 23(1), 13-21. doi: 10.1046/j.1365-2605.2000.t0 $1-1-00198 . x$

Valcarcel, J., Novoa-Carballal, R., Pérez-Martín, R. I., Reis, R. L., \& Vázquez, J. A. (2017). Glycosaminoglycans from marine sources as therapeutic agents. Biotechnology Advances, 35(6), 711-725. doi: 10.1016/j. biotechadv.2017.07.008

Zhang, Y. Z., Zhang, S. C., Liu, X. Z., Xu, Y. Y., Wang, C. L., Sawant, M. S.,... Chen, S. L. (2003). Cryopreservation of flounder (Paralichthys olivaceus) sperm with a practical methodology. Theriogenology, 60(5), 989-996. doi: 10.1016/S0093-691X (03)00097-9

Zhang, Y., Duan, X., \& Zhuang, Y. (2012). Purification and characterization of novel antioxidant peptides from enzymatic hydrolysates of tilapia (Oreochromis niloticus) skin gelatin. Peptides, 38(1), 1321. doi: 10.1016/j.peptides.2012.08.014 
